eighteen inches may be too little; but here an assured minimum of ten, or even eight inches, would rob farming of all its terrors.

Kingsburg, Fresno county, Cal.,
Jan. 13 .

S. E. MofFETT

The use of slips in scientific correspondence

To find that different workers have independently reached the same conclusions, or that they have adopted the same expedients to facilitate their work, is an evidence of the justness of the conclusions, or the excellence of the expedients. This reflection is suggested by the perusal of Professor Wilder's note of above title in Science of 16th inst, p. 44 . At the time (May 15, 1867) when Professor Wilder announced to the Boston society of natural history his use of slip-notes, I remarked that I had used slips in a similar manner; and now I can say that my principal colleague in the editorship of Psyche, Dr. George Dimmock, has for a long time exchanged with me, and probably with others, correspondence-slips for purposes similar to those described by Professor Wilder, and that I have used the card-catalogue system with profit for all the purposes mentioned by Professor Wilder and for others.

The essential features of slip-systems for filing away notes are the use of a standard or uniform size of paper for all purposes, and the entry of but one subject on a slip. After many and various experiments in the attempt to combine these features with others which are desirable, I have found the following arrangement the most convenient for all files which are not kept as card-catalogues purely. I procure thin manila sheets, 23 by 15 centimetres, or about 9 by 6 inches, which are perforated with a cutting-punch near the left margin, at distances of 13.5 centimetres from the right margin, and $2.5,7.5,16$, and 21 centi-

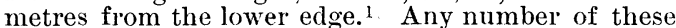
can be bound together by shaking them into place, and passing a twine or thread through the perforations, which all correspond. Slips, of whatever size or shape, not exceeding 23 by 13.5 centimetres in size, can be lightly attached to the right-hand pages by mucilage on two or more corners of the slip. These can be extended, rewritten, or removed, without removing the sheets to which they are attached. The whole of the left-hand page serves for catch-words, classificatory headings and sub-headings, or whatever matter of similar character may be desired, referring to the reverse of the page. New leaves can be inserted, or old ones removed; in a short time, while at all times the notes have the advantage of being in book form, and free from the dangers of accidental displacement, as, for instance, by a gust of wind, or by dropping the package. For rapidity and ease of reference, I know of no better system. The removal of slips from envelopes, and replacing them, take a great deal of time; and the keeping of slips in card-catalogue form prevents a rapid survey of the material in hand. If it is desired to spread the whole material out on one surface, the strings can be withdrawn from the leaves.

The same manila sheets can be used for mounting newspaper scraps for permanent preservation; and pamphlets, circulars, etc., can be perforated with corresponding holes, so that all may be tied together in any sequence desired, and temporary covers, similarly perforated, may be placed on each brochure.

B. PrCKMAN MANN.

Washington, D.C., Jan. 19, 1885.

1 For an article by me on standard holes for temporary binding, eee Lil, ary journal, January, 1883, vol. viji. pp. 6,7 .

\section{THE DECADENCE OF SCIENCE ABOUT BOSTON.}

A Bostonian, prouil of the scientific fame of his native place, and yet only too familiar with empty benches at the ordinary scientific assemblages, and to whom the election of new members, 'postponed for want of a quorum,' is a standard event, when he visits Baltimore and Washington, begins to ask whether the sceptre has not departed from Israel. He is thereafter a little shy about inviting a brother physicist from Baltimore to attend a meeting of the academy, or taking a naturalist from Washington into a session of the natural history society. To a friend about to visit the national capital, he unburdens himself with sad forebodings of the decadence of science at home; but 'tell it not in Gath,' he whispers as he parts. Nevertheless, it is an open secret.

The actual state of things is simply this, that the meetings of scientific societies at Washington and at Baltimore are much more numerous and more specialized than at Boston and Cambridge, and present at nearly every session a more varied and interesting assortment of papers, which receive wider and freer discussion at the hands of much larger audiences. So far as interest and attendance go, the meeting in the southern city is what it formerly was in the northern; and it is a pleasant and yet sad reminiscence of earlier and better days for a scientific man from Massachusetts to visit his confreres at the south. He sees again the freshness and eagerness he was wont to see at home. The audience does not sit around the rear door, hat in hand.

It is not easy to see the exact reason for all this changed aspect of affairs in the north. Assuredly, never was more expected of science than at the present day. All men attend her words. Is it that each specialist has become so engrossed in the little corner of the universe he cultivates that he can scarcely see beyond that corner, and must needs keep to it even when he shows its products? Yet why should one's mental horizon be narrower at Boston 